\title{
MANAGEMENT OF PATIENTS WITH RECTOCELE, MULTIPLE PELVIC FLOOR DYSFUNCTIONS AND OBSTRUCTED DEFECATION SYNDROME
}

\author{
Sthela Maria MURAD-REGADAS ${ }^{1}$, Francisco Sergio P. REGADAS ${ }^{2}$, \\ Lusmar Veras RODRIGUES ${ }^{3}$, Graziela Olivia da Silva FERNANDES ${ }^{4}$, \\ Guilherme BUCHEN ${ }^{4}$ and Viviane T. KENMOTI ${ }^{4}$
}

\begin{abstract}
Context - Management of patients with obstructed defecation syndrome is still controversial. Objective - To analyze the efficacy of clinical, clinical treatment followed by biofeedback, and surgical treatment in patients with obstructed defecation, rectocele and multiple dysfunctions evaluated with echodefecography. Methods - The study included 103 females aged 26-84 years with obstructed defecation, grade-II/III rectocele and multiple dysfunctions on echodefecography. Patients were distributed into three treatment groups and constipation scores were assigned. Group I: 34 (33\%) patients with significant improvement of symptoms through clinical management only. Group II: $14(14 \%)$ with improvement through clinical treatment plus biofeedback. Group III: $55(53 \%)$ referred to surgery due to treatment failure. Results - Group I: $20(59 \%)$ patients had grade-II rectocele, 14 (41\%) grade-III. Obstructed defecation syndrome was associated with intussusception (41\%), mucosal prolapse (41\%), anismus ( $29 \%)$, enterocele $(9 \%)$ or 2 dysfunctions (23\%). The average constipation score decreased significantly from 11 to 5. Group II: 11 (79\%) grade-II rectocele, $3(21 \%)$ grade-III, associated with intussusception (7\%), mucosal prolapse $(43 \%)$, anismus $(71 \%)$ or 2 dysfunctions $(29 \%)$. There was significant decrease in constipation score from 13 to 6 . Group III: $8(15 \%)$ grade-II rectocele, 47 (85\%) grade-III, associated with intussusception $(42 \%)$, mucosal prolapse $(40 \%)$ or 2 dysfunctions $(32 \%)$. The constipation score remained unchanged despite clinical treatment and biofeedback. Twenty-three underwent surgery had a significantly decrease in constipation score from 12 to 4. The remaining 32 (31\%) patients which 22 refused surgery, 6 had low anal pressure and 4 had slow transit. Conclusions - Approximately $50 \%$ of patients with obstructed defecation, rectocele and multiple dysfunctions presented a satisfactory response to clinical treatment and/or biofeedback. Surgical repair was mainly required in patients with grade-III rectocele whose constipation scores remained high despite all efforts.
\end{abstract}

HEADINGS - Rectocele. Constipation. Pelvic floor. Imaging, three-dimensional.

\section{INTRODUCTION}

Constipation is a clinical symptom present in patients suffering from slow transit and/or obstructed defecation. Proper treatment requires the identification of all associated dysfunctions and the quantification of symptoms (most often excessive straining, feeling of incomplete evacuation, difficult evacuation, infrequent evacuation and the need for digitally assisted evacuation) by means of a scoring system ${ }^{(1,2,19)}$. Obstructed defecation syndrome is associated with anatomic changes (rectocele, intussusception, mucosal prolapse and perineal descent) and/or functional changes (non-relaxation or paradoxical contraction/ anismus) a complete clinical investigation is required, if possible with techniques capable of identifying all dysfunctions.

Rectocele is a common cause of constipation due to obstructed defecation, although it may also be observed in asymptomatic subjects ${ }^{(29,31)}$. Radiologic methods for the dynamic evaluation of the obstructed defecation syndrome (ODS) include defecography, magnetic resonance imaging and ultrasonography, each of which has its advantages and limitations $^{(4,5,6,10,14,20,22,24,25,28,32)}$. Different dynamic ultrasound techniques have been used to evaluate pelvic floor dysfunctions and demonstrated good correlation with conventional defecography ${ }^{(4,6,10,28)}$. One such technique, echodefecography (three-dimensional dynamic anorectal ultrasonography), developed

\footnotetext{
None disclosure.

${ }^{1}$ Adjunct Professor, Department of Surgery, School of Medicine of the Federal University of Ceará. Head of the Department of Anorectal Physiology. Clinical Hospital. Federal University of Ceará; ${ }^{2}$ Full Professor, Department of Surgery, School of Medicine of the Federal University of Ceará; ${ }^{3}$ Adjunct Professor, Department of Surgery, School of Medicine of the Federal University of Ceará; ${ }^{4}$ Colorectal Surgeon. Master's Degree in Digestive Surgery, School of Medicine of the Federal University of Ceará, CE, Brazil. Correspondence: Prof. Sthela M. Murad-Regadas - Rua Atilano de Moura, 430, ap. 200 - 60810-180 - Fortaleza, Ceará, Brazil. E-mail: smregadas@hospitalsaocarlos.com.br
} 
by Murad-Regadas et al. ${ }^{(28)}$, has been shown to correlate well with defecography and was validated in a prospective multicenter study ${ }^{(28,32)}$. Echodefecography provides a visualization of all pelvic floor structures and changes during straining, making it possible to evaluate voiding disorders affecting posterior compartment (rectocele, rectal intussusception, anismus and mucosal prolapse) or the middle compartment (entero/sigmoidocele grade III).

Different treatment modalities have been proposed for the management of patients with ODS. Unfortunately, results have so far been conflicting and no clear consensus has been reached ${ }^{(13,21,27)}$.

The purpose of the present study was to analyze the efficacy of clinical, biofeedback, and surgical treatment in patients with obstructed defecation, rectocele and multiple dysfunctions evaluated with echodefecography.

\section{METHODS}

Between March 2008 and February 2009, 175 female patients with ODS (excessive straining, vaginal splinting and sensation of incomplete evacuation) aged 54 years on the average (range: $26-84$ ) with a Wexner's ${ }^{(1)}$ constipation score of $\geq 6.0$ (range: $6-18$ ) were submitted to physical examination and anamnesis. All patients were evaluated with dynamic 3D anorectal ultrasonography (echodefecography) to identify pelvic floor dysfunctions in the posterior compartment involving anal canal and inferior rectum (including Grade I, II and III rectocele, rectal intussusception, prolapse of the anal canal mucosa and anismus or non-relaxation) and in the middle compartment involving vagina and uterus (Grade III enterocele/sigmoidocele). Patients with anal sphincter injury, fecal incontinence, symptoms of stress and urge urinary incontinence and/or history of colorectal and proctological surgery were excluded, as were patients without rectocele or non significant rectocele (grade I). A total of 103 patients with ODS and significant rectocele (Grade II or III) on echodefecography, isolated or associated with other dysfunctions, were included in the study.

Initially, all patients received clinical treatment for 3 months. Based on individual assessments, patients were subsequently assigned to three treatment groups according to observed improvement of symptoms and echodefecographic findings: patients in Group I continued to receive clinical treatment only, in view of the success of the first 3 months of management. Group II included patients with insufficient response to initial clinical management and diagnosis of anismus or absence of relaxation on echodefecograpfy. These patients were assigned to clinical management combined with biofeedback therapy. Finally, due to insufficient response to clinical management and biofeedback therapy, patients in Group III were referred to surgical treatment. Complementary tests, including anorectal manometry, rectal sensitivity, maximum tolerable volume and colonic transit analysis (patients reporting less than three defecations per week) were performed prior to surgery. It was determined that low anal canal pressure on anorectal manometry and slow transit on colonic transit analysis were surgical contraindications. Treatment success was defined as $\geq 40 \%$ decrease in constipation symptoms as reflected by improvements in Wexner's ${ }^{(1)}$ constipation score. The patients were followed for 3-6 months.

The evaluated parameters (age, history of vaginal delivery and constipation score before and after treatment) were compared between the groups.

The study was previously approved by the hospital's research ethics committee and all patients gave their informed consent.

\section{3-D dynamic anorectal ultrasonography (echodefecography)}

3-DAUS was performed with a 3-D ultrasound scanner (Pro-Focus, endoprobe model 2052, B-K Medical ${ }^{\circledR}$, Herlev, Denmark) as described in previous publications by MuradRegadas et al. ${ }^{(28)}$. Following rectal enema, patients were examined in the left lateral position. Images were acquired by three automatic scans and analyzed in the axial, sagittal and, if necessary, in the oblique plane by a single colorectal surgeon (SMMR) with experience in 3-DAUS.

\section{Scanning}

- Scan 1 - evaluation of the anatomical integrity of the anal sphincters at rest.

- Scan 2 - the transducer was positioned at $6.0 \mathrm{~cm}$ from the anal verge. The patient was requested to rest during the first 15 seconds, strain maximally for 20 seconds and then relaxes again, with the transducer following the movement. The purpose of the scan was to evaluate the movement of the PR and the external anal sphincter during straining, identifying normal relaxation, nonrelaxation or paradoxical contraction (anismus) and prolapse of the anal canal mucosa.

- Scan 3 - following injection of $120-180 \mathrm{~mL}$ ultrasound gel into the rectal ampulla, the transducer was positioned at $7.0 \mathrm{~cm}$ from the anal verge. The scanning sequence was the same as in Scan 2, visualizing and quantifying all anatomical structures and functional changes associated with voiding (rectocele, intussusception, Grade-III sigmoidocele/enterocele).

Rectocele grade was previously defined through a comparison between echodefecography and defecography ${ }^{(28,32)}$ (Figures 1 and 2). The measurement of rectocele grade were calculates by first drawing two parallel horizontal lines along the posterior vaginal wall, with one line placed in the initial straining position and the other line drawn at the point of maximal straining. The distance between the two vaginal wall positions determined the size of the rectocele, grade I $(<6.0 \mathrm{~mm})$, grade II $(6.0-13.0 \mathrm{~mm})$, or grade III $(>13.0 \mathrm{~mm})$

\section{Clinical treatment}

Clinical treatment included the administration of a fiberrich diet (up to $30 \mathrm{~g}$ bran/day), liquid (up to $2 \mathrm{~L} /$ day) and bulk laxative for 3 months. 


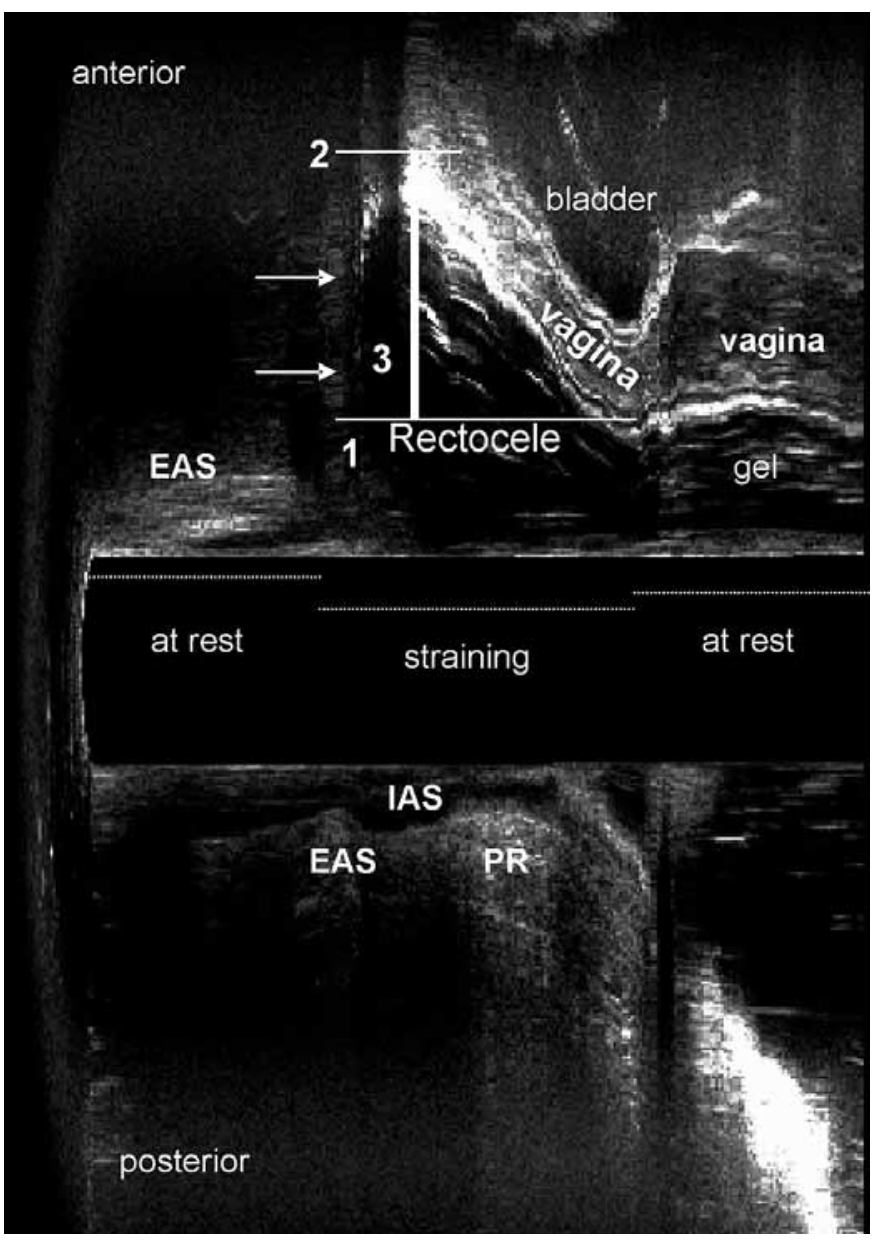

FIGURE 1. Patient with grade III rectocele (arrows) (Sagittal plane). Using gel into the rectum

Line 1 - Parallel with the vagina wall during initial straining

Line 2 - Parallel with the vagina wall at maximal herniation point Line 3 - Length between lines 1 and 2 (Rectocele size)

EAS $=$ External anal sphincter IAS $=$ Internal anal sphincter $\mathrm{PR}=\mathrm{Pu}-$ borectal

\section{Biofeedback therapy}

Patients were submitted to biofeedback therapy twice a week for up to 10 sessions. All subjects were managed as outpatients. Patients were given detailed information about biofeedback therapy and the anatomy and physiology of the pelvic floor ${ }^{(13)}$. Expulsion was practiced using anorectal manometry and an 8-lumen catheter with a balloon attached to the tip. The catheter was inserted in the anal canal and the subjects were allowed to view the pressure recordings. Patients were instructed to look for changes in pressure, with special attention to the response of the anal sphincter during squeezing and straining, and were taught how to relax the sphincter during expulsion of the rectal balloon at the urge threshold (indicated by a decrease in basal pressure), relax the pelvic floor muscles and delicately press downwards using the abdominal muscles.

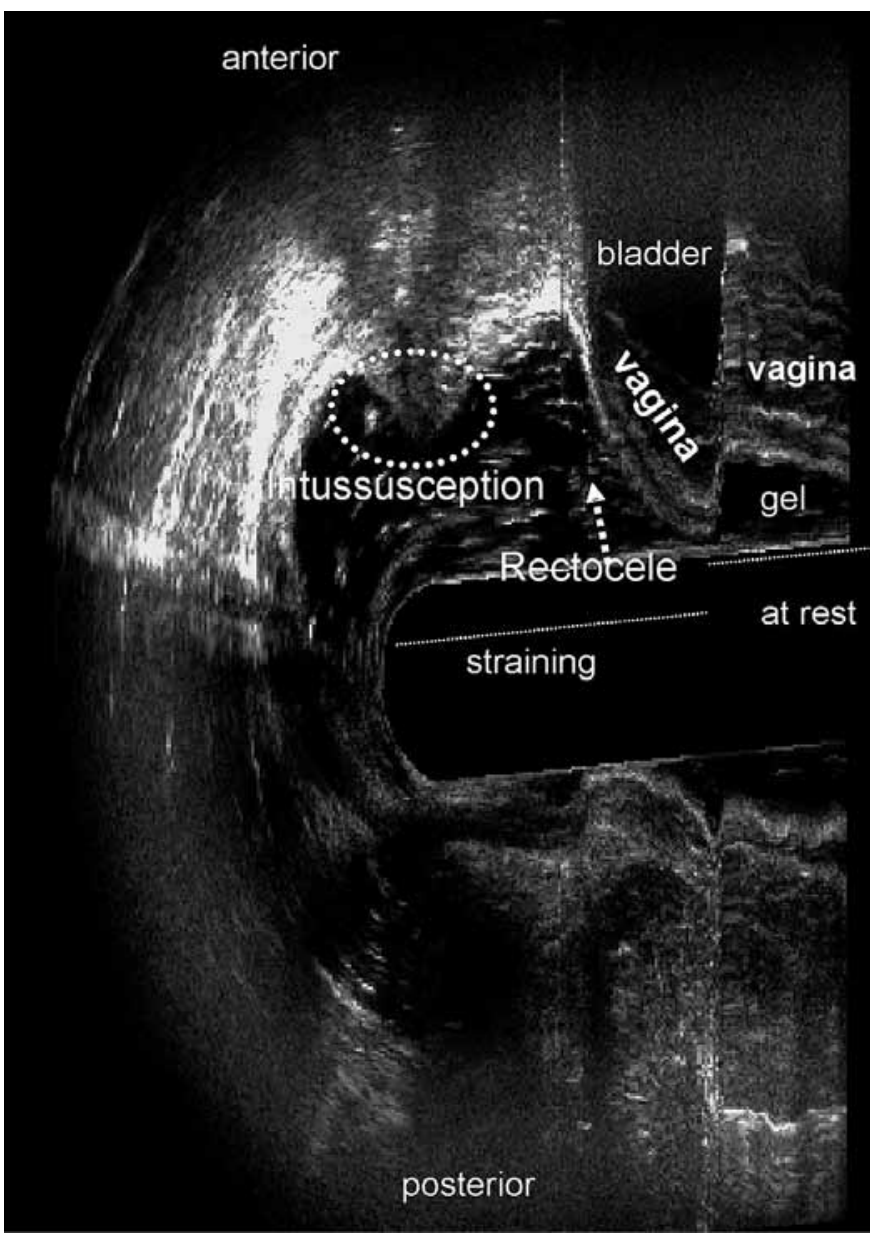

FIGURE 2. Rectocele grade III (arrow) and anterior rectal intussusception (circle) (Axial and sagittal planes). Using gel into the rectum

\section{Anorectal manometry, rectal sensitivity and maximum tolerable volume}

Anorectal manometry was performed using a flexible, water-perfused polyethylene catheter with an 8-channel ProctoMaster Dynamed ${ }^{\circledR}$ manometer, calculating the length of the anal canal, the anal canal pressure at rest, maximum anal squeezing; the capacity required to sustain squeeze pressure and the rectoanal reflex. Rectal sensitivity (corresponding to the first sensation of rectal filling) and the maximum tolerable volume were measured. All evaluations were performed by the same examiner.

\section{Colonic transit study}

The colonic transit time was measured using radiopaque markers for detection of slow transit, as described by Hinton et al. ${ }^{(15)}$

\section{Surgical technique}

All patients were operated on by a team of 3 colorectal surgeons specialized in coloproctology (Brazilian Board of Colorectal Surgery). The TRREMS procedure (transanal 
repair of rectocele and rectal mucosectomy using a single circular stapler) was used, as previously described by Cruz et al. ${ }^{(9)}$. After a full mechanical bowel preparation, patients were placed in the Lloyd-Davis position under spinal anesthesia. Broad-spectrum antibiotic prophylaxis was administered prior to surgery. A circular anal dilator was inserted into the anal canal and maintained secured to the perianal skin with two stay sutures (anterior and posterior). The rectocele was pushed through the anal canal with a finger inserted into the vagina to identify the apex of the rectocele (Figure 3 ).

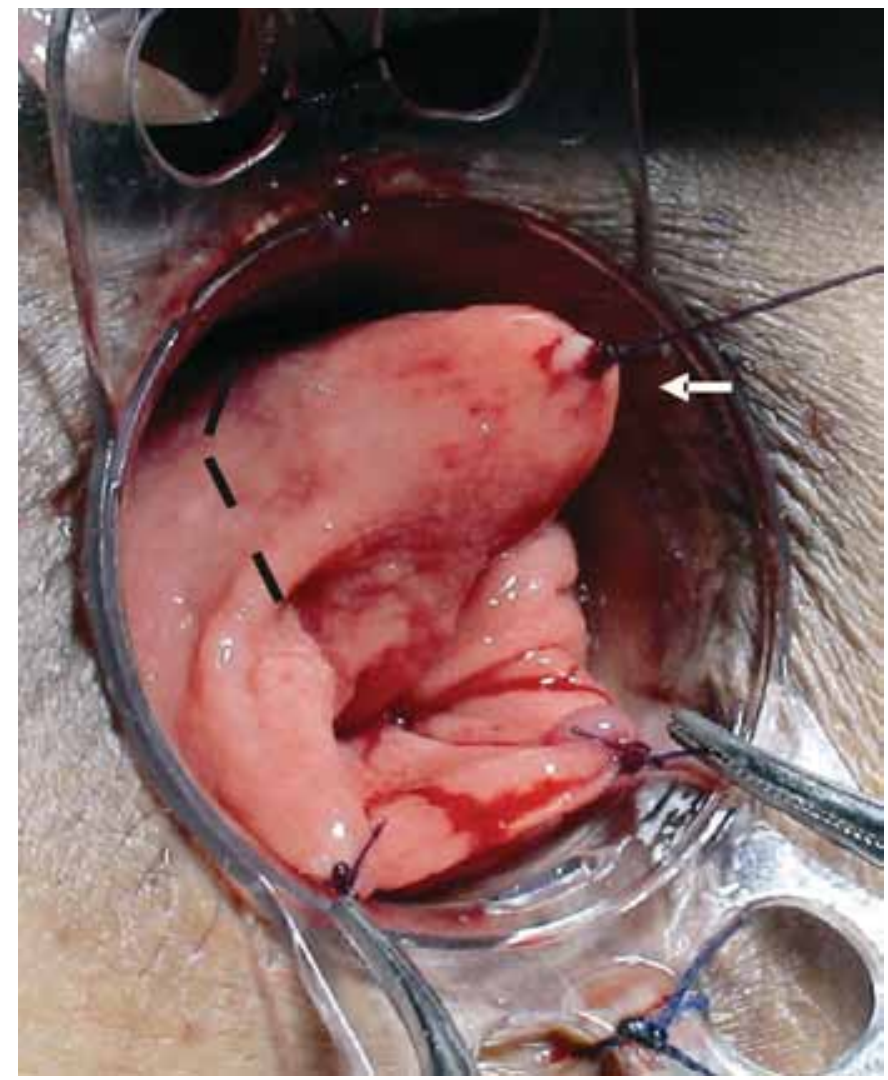

FIGURE 3. The apex of the rectocele is identified and pulled down through a stitch (arrow). Site of the horizontal running suture (black lines)

A running horizontal suture (Greek suture technique) was placed through the base of the rectocele, including mucosa, submucosa and the muscle layer, approximately $1.5 \mathrm{~cm}$ above the dentate line, depending on the size of the rectocele. Following that, the whole rectocele wall is excised with an electrical scalpel, just above the running suture (Figure 4). A continuous purse string rectal mucosa suture was then placed envolving only mucosa and submucosa. The stapler was then inserted through the pursestring suture, which was subsequently tied around the stapler's center rod, taking care to include the tissue with the running horizontal suture anteriorly (Figure 5). The stapler was fired, producing a circular suture, and withdrawn.

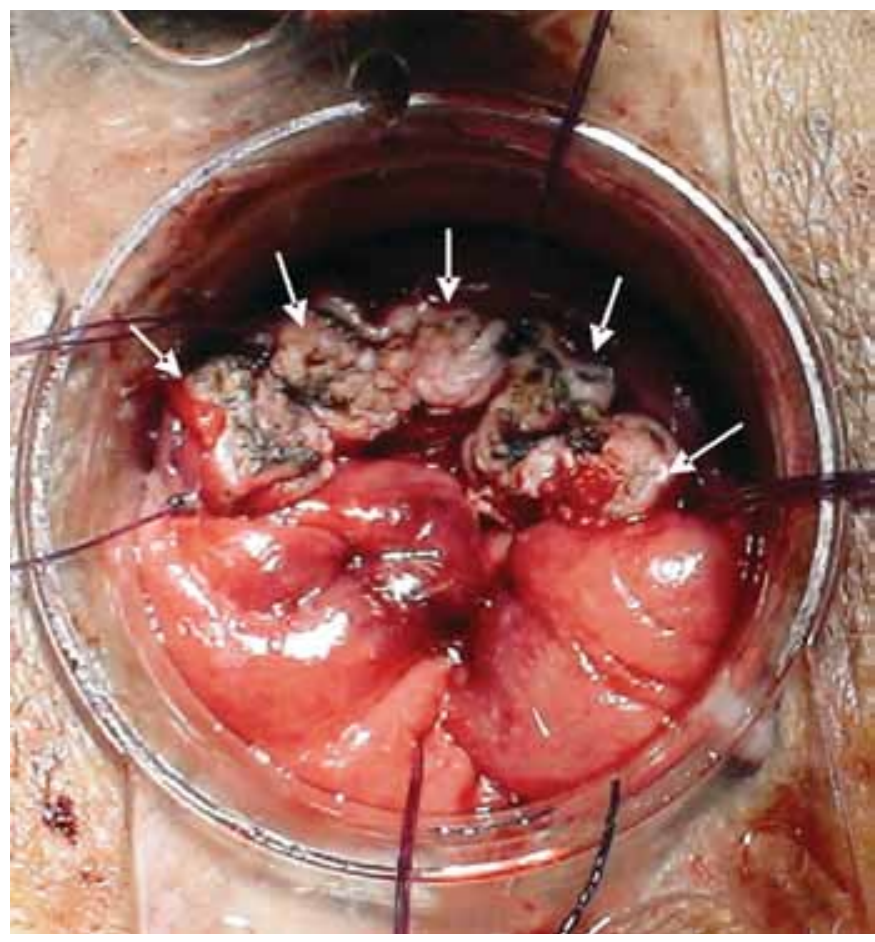

FIGURE 4 . The exceeded prolapsed mucosa and the muscular layer were excised, keeping an opened wound with the edges joined by the previous manual suture (arrows)

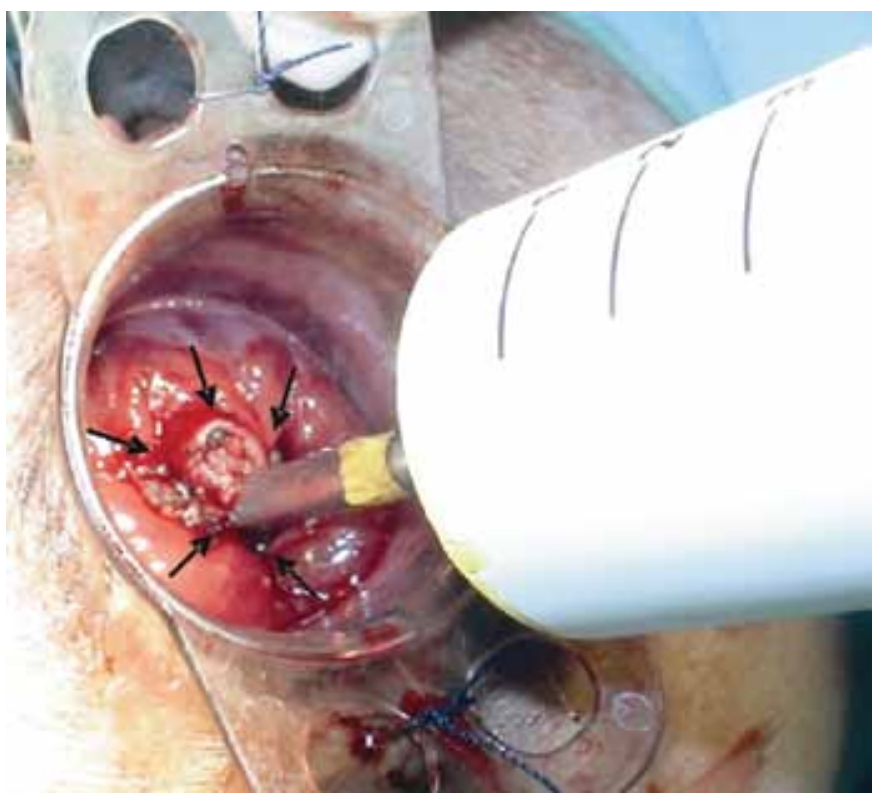

FIGURE 5. The pursestring suture is tied around the stapler's center rod (arrows)

\section{Statistical analysis}

Student's $t$ test and the Chi-square test were used to compare all measurements. The level of statistical significance was set at $P<0.05$. All analyses were performed with SPSS version 13.0 for Windows ${ }^{\circledR}$. 


\section{RESULTS}

Group I included 34/103 (33\%) patients (mean age: 51.6 \pm 2.066 ; range $26-72)$. Of these, $14(41 \%)$ had a history of at least one vaginal delivery. The distribution of the dysfunctions is shown in Table 1. The average constipation score fell from $10.85 \pm 0.5943$ (range: $6-18$ ) before clinical management to $5.41 \pm 0.2502$ (range: $3-8$ ) after clinical management $(P<0.0001)$. Fourteen patients with mucosal prolapse were treated with rubber band ligation without complications.

TABLE 1. Distribution of grade II or III rectocele and multiple pelvic floor dysfunctions in the groups

\begin{tabular}{|c|c|c|c|}
\hline $\begin{array}{l}\text { Pelvic floor } \\
\text { dysfunctions }\end{array}$ & $\begin{array}{c}\text { Group I } \\
\mathrm{n}=34(33 \%)\end{array}$ & $\begin{array}{c}\text { Group II } \\
\mathrm{n}=14(14 \%)\end{array}$ & $\begin{array}{c}\text { Group III } \\
\mathrm{n}=55(53 \%)\end{array}$ \\
\hline Rectocele (grade II) & $20(59 \%)$ & $11(79 \%)$ & $8(15 \%)$ \\
\hline Rectocele (grade III) & $14(41 \%)$ & $3(21 \%)$ & $47(85 \%)$ \\
\hline $\begin{array}{l}\text { Rectal } \\
\text { intussusception }\end{array}$ & $14(41 \%)$ & $1(7 \%)$ & $23(42 \%)$ \\
\hline Mucosal prolapse & $14(41 \%)$ & $6(43 \%)$ & $22(40 \%)$ \\
\hline $\begin{array}{l}\text { Anismus or } \\
\text { non-relaxation }\end{array}$ & $10(29 \%)$ & $14(100 \%)$ & $4(7 \%)$ \\
\hline $\begin{array}{l}\text { Enterocele/ } \\
\text { sigmoidocele } \\
\text { (grade III) }\end{array}$ & $3(9 \%)$ & - & - \\
\hline Two dysfunctions & $8(23 \%)$ & $4(29 \%)$ & $18(32 \%)$ \\
\hline $\begin{array}{l}\text { Decrease in } \\
\text { constipation score }\end{array}$ & $\begin{array}{l}10.85 » 5.41 \\
(P<0.0001)\end{array}$ & $\begin{array}{l}13.18 » 6.54 \\
(P<0.0001)\end{array}$ & $\begin{array}{l}12.39 » 3.78 \\
(P<0.0001)\end{array}$ \\
\hline
\end{tabular}

Group II included 14/103 (14\%) patients (mean age: 59.50 \pm 4.328 ; range: $34-81)$. Of these, $6(43 \%)$ had a history of at least one vaginal delivery. The distribution of the dysfunctions is shown in Table 1. The average constipation score fell from $13.18 \pm 0.7112$ (range: $8-16$ ) before clinical management to $6.54 \pm 0.3900$ (range: $4-8$ ) after clinical management $(P<0.0001)$. Six patients with mucosal prolapse were treated with rubber band ligation without complications.

Group III included 55/103 (53\%) patients (mean age: 53.58 \pm 1.485 ; range: $34-73)$. Of these, $20(23 \%)$ had a history of at least one vaginal delivery. The distribution of the dysfunctions is shown in Table 1 . The average preoperative constipation score (12.27 \pm 0.2454 ; range: $10-16)$ was not affected by clinical treatment combined with biofeedback. All patients referred to surgery were submitted to anorectal manometry and determination of rectal sensitivity and maximum tolerable volume. Eight of these also had a colonic transit study. Twenty-three of the patients in Group III $(23 / 103 ; 22 \%)$ underwent surgery. Of these, $16(70 \%)$ had Grade-III rectocele and $7(30 \%)$ had Grade-II. Rectocele was associated with rectal intussusception in $10(44 \%)$, mucosal prolapse in $6(26 \%)$, absence of relaxation in $2(9 \%)$ and more than two dysfunctions in $10(44 \%)$ patients. No intraoperative complications were observed. Two (8.7\%) patients experienced minor postoperative complications: one developed stricture on the stapled suture subsequently treated with digital dilatation ( 3 sessions), the other complained of persistent rectal pain for 2 weeks. When reevaluated 3-6 months (mean $4.6 \pm 0.9672$ ) after surgery, the average constipation score had fallen from $12.39 \pm 0.4013$ (range: $10-16$ ) to $3.78 \pm 0.5106$ (range: $1-7)(P<0.0001)$. The remaining 32 patients $(31 \%)$ were not submitted to surgery due to refusal $(\mathrm{n}=22)$ or surgical contraindications (low anal pressure $n=6$; slow transit $n=4$ ).

No statistical significance was found between the groups with regard to age and presence of vaginal delivery. Constipation scores were significantly higher in Group II (13.18) and Group III (12.27) than in Group I (10.85) $(P=0.0099)$. Grade-III rectocele was significantly more frequent in Group III $(P<0.0001)$, but the groups did not differ significantly with regard to intussusception, mucosal prolapse, anismus or Grade-III enterocele/sigmoidocele (Table 1) (Figure 6). The

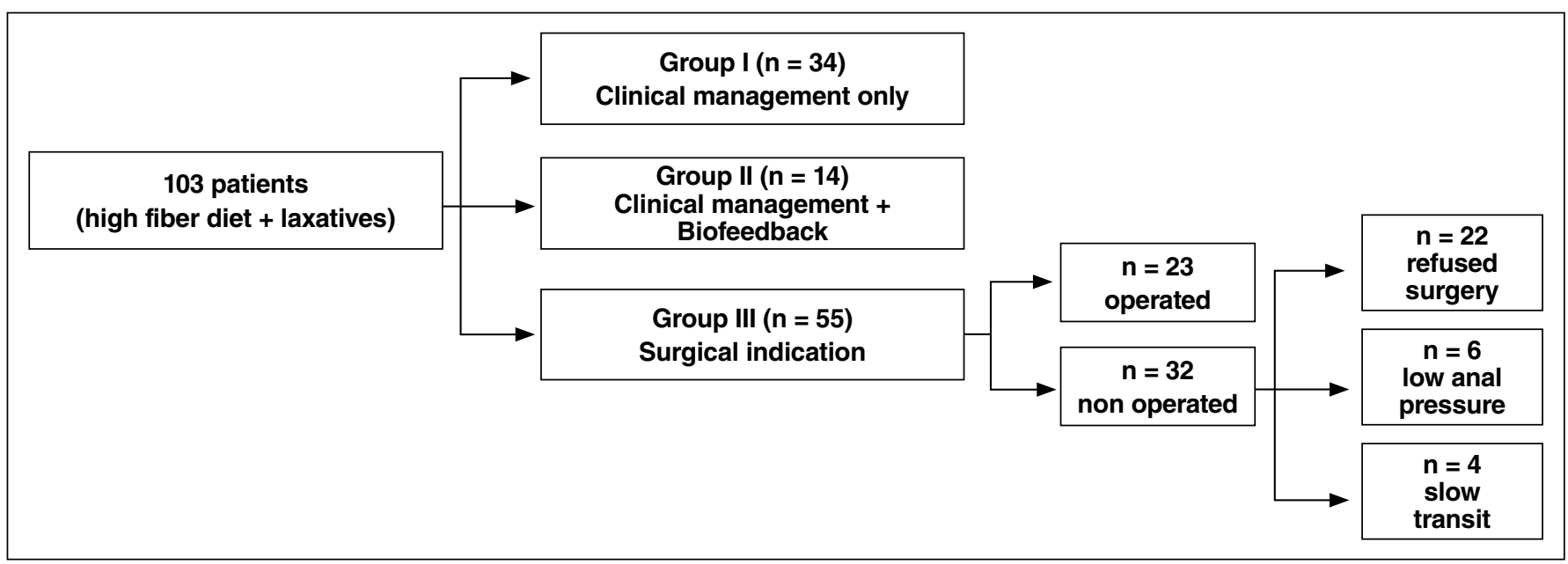

FIGURE 6. Algorithm for the management of patients with significant rectocele, multiple pelvic floor dysfunctions and obstructed defecation syndrome 
anorectal manometry findings were normal for 23 patients in Group III. In 6 patients the mean basal pressure was reduced by $20 \%-30 \%$. Colonic transit was normal in 23 patients from Group III. Slow transit was observed in the left part of the colon in 4 patients.

\section{DISCUSSION}

Obstructed defecation may involve anatomic and functional changes that are potentially difficult to manage. Many forms of treatment have been proposed with varying results, including fiber ingestion, laxatives, biofeedback therapy, electrostimulation, sacral nerve stimulation and surgical repair $^{(8,9,12,13,21,23,27)}$.

A total of 175 patients with obstructed defecation syndrome and a Wexner's constipation score $\geq 6$. 0 were assessed with 3-D dynamic anorectal ultrasonography (echodefecography) to identify pelvic floor dysfunctions in the posterior compartment (rectocele, intussusception, mucosal prolapse and anismus) and the middle compartment (Grade-III enterocele/sigmoidocele). Eventually, 103 patients with clinically significant rectocele were selected to analyze the efficacy of clinical treatment, clinical treatment combined with biofeedback therapy, and surgical repair. Although a specific scoring system for obstructed defecation syndrome has been proposed ${ }^{(2,19)}$, at our institution, Wexner's constipation score has been widely used in investigations involving functional constipation symptoms.

The echodefecography techniques and parameters used in the present study have been described previously by Murad-Regadas et al. ${ }^{(28)}$ and Regadas et al. ${ }^{(32)}$, who also demonstrated the agreement between echodefecography and defecography. The advantage of echodefecography lies in the possibility of visualizing all the anatomical structures of the pelvic floor, changes during straining and evacuation disorders without exposing the patient to radiation. On the other hand, the technique can not be used to quantify contrast retention. Some authors have suggested that rectocele should not be repaired if the contrast is completely eliminated during defecography ${ }^{(26)}$. Others have failed to demonstrate any correlation between defecography findings and surgical outcome $^{(14,16)}$. Nevertheless, rectocele is rather frequently observed in asymptomatic nulliparous volunteers ${ }^{(34)}$.

In this study the constipation score improved without surgical repair in approximately half the patients (clinical management alone $=33 \%$; clinical management + biofeedback $=13.6 \%$ ). Dietz et al. ${ }^{(11)}$ believe that when determining the etiology of symptoms of obstructed defecation, stool quality is of greater relevance than the presence of rectocele. Rectocele was associated with anismus or absence of relaxation in $28 / 103(27 \%)$. In the literature, anismus is associated with clinically significant rectocele in $20 \%-80 \%$ of cases $^{(17,26)}$. Biofeedback therapy with anorectal manometry was administered to $18 / 103$ patients with multiple dysfunctions and anismus or non-relaxation. Symptoms improved in 14/18 (77.8\%; Group II). The remaining 4 (22\%; Group III) were referred to surgical repair. Our results match findings from other series ${ }^{(12,26)}$. The two most common forms of biofeedback therapy are anal manometry (used in the present study) and electromyography of the anal sphincter ${ }^{(13)}$. On the other hand, symptoms improved without biofeedback therapy in $10 / 103$ patients $(10 \%$; Group I) with multiple dysfunctions and anismus treated with fiber and bulk laxatives.

Different techniques have been used to treat patients with obstructed defecation associated with anatomical abnormalities such as rectocele, rectal intussusception and mucosal prolapse ${ }^{(18,21,36)}$. Successful outcomes have been reported in $62 \%-85 \%$ of cases, but the available data are difficult to analyze due to differences in indications (symptoms and laboratory findings) and criteria for the evaluation of results.

In this study, 55 patients were referred to surgical repair because clinical management with or without biofeedback therapy did not improve symptoms sufficiently. After excluding patients with slow transit and reduced anal pressure, 23 subjects were submitted to rectocele repair with the TRREMS procedure (transanal repair of rectocele and rectal mucosectomy with a single circular stapler) which makes it possible to remove the anorectal mucosa circumferentially and reinforce the anterior anorectal junction wall with the use of a single circular stapler and a novel surgical device $\mathrm{kit}^{(9)}$. The few observed complications $(2 / 23 ; 8.7 \%)$ were easily treated during hospitalization. In the literature, minor complications have been reported for stapled transanal resec$\operatorname{tion}^{(3,7)}$. In this respect, our results compare favorably to those of other series ${ }^{(21)}$. Thus, we suggest considering the criteria for surgical indication and surgical training carefully. The present study was limited by the small number of patients submitted to surgery (23 patients refused surgical treatment) and the short follow-up period (3-6 months).

Our series consisted of patients with anatomical and functional abnormalities. Clinical management was chosen as primary treatment, followed by biofeedback therapy for patients with associated anismus or non-relaxation, leading to a satisfactory decrease in constipation symptoms in approximately half the patients. Thus, the selection criteria for surgery included persistent symptoms (despite clinical management and biofeedback therapy), a constipation score of $\geq 10$, diagnosis of significant rectocele (isolated or associated with other dysfunctions) and normal colonic transit and anorectal manometry findings.

The choice of selection criteria for surgery is a controversial matter. In fact, other researchers believe specific symptoms such as the need for vaginal or rectal manipulation to empty the rectal ampulla should be included among the criteria. Although the outcome of rectocele repair tends to be poor in patients with slow transit ${ }^{(26)}$, some authors advocate surgical repair to improve the results of future colonic surgery ${ }^{(30)}$. Likewise, reduced anal pressure was considered a contraindication for surgery in this study since fecal incontinence has often been reported following stapled transanal repair ${ }^{(21)}$.

Twenty-three subjects were submitted to rectocele repair (two of whom presented no relaxation despite biofeedback therapy) followed by improvement in symptoms. In contrast, some studies have reported poor results after rectocele repair 
in patients with associated anismus ${ }^{(17)}$. In another series, no significant difference was observed ${ }^{(35)}$.

Our patients were evaluated up to 6 months after clinical/biofeedback management and 3-6 months after surgery. Symptoms decreased by at least $40 \%$. However, to establish an optimal treatment strategy, a much longer follow-up period would be required. In a multicenter study, the outcome of stapled rectal resection and biofeedback for the treatment of outlet obstruction was evaluated for 1 year after treatment: surgical repair and biofeedback therapy were successful in $81 \%$ and $33 \%$ of cases, respectively ${ }^{(21)}$. Roman et al. ${ }^{(33)}$ reported high recurrence rates after transanal rectocele repair over long-term follow-up (30-128 months) and concluded that preoperative clinical and laboratory findings are of no use in the identification of patients with high risk of recurrence.

Proper management of patients with ODS requires a complete clinical evaluation and simultaneous identification of all potential pelvic floor dysfunctions. Clinical management and biofeedback therapy should be considered as initial treatment.

In conclusion, approximately $50 \%$ of the patients with obstructed defecation symptoms, clinically significant rectocele and multiple dysfunctions presented a satisfactory response to clinical treatment and/or biofeedback therapy. Surgical repair was mainly required in patients with GradeIII rectocele and normal colonic transit whose constipation scores remained high despite all efforts.

Murad-Regadas SM, Regadas FSP, Rodrigues LV, Fernandes GOS, Buchen G, Kenmoti VT. Tratamento de pacientes com retocele, múltiplas disfunções e síndrome da evacuação obstruída. Arq Gastroenterol. 2012;49(2):135-42.

RESUMO - Contexto - O tratamento dos pacientes com evacuação obstruída permanece controverso. Objetivo - Analisar a eficácia do tratamento clínico, tratamento clínico seguido por biofeedback e tratamento cirúrgico em pacientes com retocele e disfunções do compartimento posterior do assoalho pélvico avaliados com ultrassom tridimensional dinâmico-ecodefecografia. Método - O estudo incluiu 103 mulheres, em idade entre 26-84 anos, com diagnóstico de evacuação obstruída, retocele grau II/III e disfunções múltiplas na ecodefecografia. Pacientes foram distribuídos em três grupos e registrados os escores de constipação. Grupo I: 34 (33\%) pacientes com melhora significante dos sintomas apenas com tratamento clínico. Grupo II: $14(14 \%)$ com melhora ao tratamento clínico e biofeedback. Grupo III: 55 (53\%) encaminhadas para cirurgia, sem resposta ao tratamento clínico. Resultados - Grupo I: 20 (59\%) pacientes com retocele grau II, 14 (41\%) grau III associada a intussuscepção (41\%), prolapso mucoso (41\%), anismus $(29 \%)$, enterocele $(9 \%)$ ou duas disfunções (23\%). O escore de constipação reduziu-se significantemente em média de 11 para 5. Grupo II: 11 (79\%) retocele grau II, 3 (21\%) grau III, associado a intussuscepção (7\%), prolapso mucoso (43\%), anismus $71 \%$ ou duas disfunções ( $29 \%$ ). O escore de constipação reduziu-se com significância estatística em média de 13 para 6. Grupo III: 8 (15\%) retocele grau II, 47 (85\%) grau III, associado a intussuscepção (42\%), prolapso mucoso (40\%), ou disfunções (32\%). O escore de constipação não se alterou, apesar do tratamento clínico e biofeedback. Vinte e três foram encaminhados para cirurgia resultando em redução significante do escore de constipação de 16 para 4 . Dos 32 restantes, 22 optaram por não realizar cirurgia, 6 apresentavam pressões anais reduzidas e 4 com trânsito lento. Conclusão - Aproximadamente 50\% dos pacientes com evacuação obstruída, retocele ou disfunções múltiplas apresentaram resposta satisfatória ao tratamento clínico e/ou ao biofeedback. Tratamento cirúrgico foi necessário principalmente em pacientes com retocele grau III em que o escore permaneceu inalterado apesar do tratamento clínico e biofeedback.

DESCRITORES - Retocele. Assoalho pélvico. Constipação intestinal. Imagem tridimensional. 


\section{REFERENCES}

1. Agachan F, Chen T, Pfeifer J, Reissman P, Wexner SD. A constipation scoring system to simplify evaluation and management of constipated patients. Dis Colon Rectum. 1996;39:681-5.

2. Altomare DF, Spazzafumo L, Rinaldi M, Dodi G, Ghiselli R, Piloni V. Set-up and statistical validation of a new scoring system for obstructed defaecation syndrome. Colorectal Dis. 2008;10:84-8.

3. Arroyo A, Pérez-Vicente F, Serrano P, Sánchez A, Miranda E, Navarro JM, Candela F, Calpena R. Evaluation of the stapled transanal rectal resection technique with two staplers in the treatment of obstructive defecation syndrome. J Am Coll Surg. 2007;204:56-63.

4. Barthet M, Portier F, Heyries L, Orsoni P, Bouvier M, Houtin D, Barriere N, Mambrini P, Salducci J, Grimaud JC. Dynamic anal endosonography may challenge defecography for assessing dynamic anorectal disorders: results of a prospective pilot study. Endoscopy. 2000;32:300-5.

5. Bartram CI, Turnbull GK, Lennard-Jones JE. Evacuation proctography: an investigation of rectal expulsion in 20 subjects without defecatory disturbance. Gastrointest Radiol. 1988;13:72-80.

6. Beer-Gabel M, Teshler M, Schechtman E, Zbar AP. Dynamic transperineal ultrasound vs. defecography in patients with evacuatory difficulty: a pilot study. Int J Colorectal Dis. 2004;19:60-7.

7. Boccasanta P, Venturi M, Salamina G, Cesana BM, Bernasconi F, Roviaro G New trends in the surgical treatment of outlet obstruction: clinical and functional results of two novel transanal stapled techniques from a randomised controlled trial. Int J Colorectal Dis. 2004;19:359-69.

8. Chiarioni G, Chistolini F, Menegotti M, Salandini L, Vantini I, Morelli A, Bassotti G. One-year follow-up study on the effects of electrogalvanic stimulation in chronic idiopathic constipation with pelvic floor dyssynergia. Dis Colon Rectum. 2004; $47: 346-53$.

9. Cruz JV, Regadas FS, Murad-Regadas SM, Rodrigues LV, Benicio F, Leal R, Carvalho CG, Fernandes M, Roche LM, Miranda AC, Câmara L, Pereira JC, Parra AM, Leal VM. TRREMS procedure (Transanal repair of rectocele and rectal mucosectomy with one circular stapler): a prospective multicenter trial. Arq Gastroenterol. 2011;48:3-7.

10. Dietz HP, Haylen BT, Broome J. Ultrasound in the quantification of female pelvic organ prolapse. Ultrasound Obstet Gynecol. 2001;18:511-4.

11. Dietz HP. Rectocele or stool quality: what matters more for symptoms of obstructed defecation? Tech Coloproctol. 2009;13:265-8.

12. Gilliland R, Heymen S, Altomare DF, Park UC, Vickers D, Wexner SD. Outcome and predictors of success of biofeedback for constipation. Br J Surg. 1997;84:1123-6.

13. Glia A, Gylin M, Gullberg K, Lindberg G. Biofeedback retraining in patients with functional constipation and paradoxical puborectalis contraction: comparison of anal manometry and sphincter electromyography for feedback. Dis Colon Rectum. 1997;40:889-95.

14. Halligan S, Bartram CI. Is barium trapping in rectoceles significant? Dis Colon Rectum. 1995;38:764-8.

15. Hinton JM, Lennard-Jones JE, Young AC. A new method for studying gut transit time using radiopaque markers. Gut. 1969;10:842-7.

16. Janssen LW, van Dijke CF. Selection criteria for anterior rectal wall repair in symptomatic rectocele and anterior rectal wall prolapse. Dis Colon Rectum. 1994;37:1100-7.

17. Johansson C, Nilsson BY, Holmström B, Dolk A, Mellgren A. Association between rectocele and paradoxical sphincter response. Dis Colon Rectum. 1992;35:503-9.

18. Kahn MA, Stanton SL. Posterior colporrhaphy: its effect on bowel and sexual function. Br J Obstet Gynaecol. 1997;104:82-6.
19. Knowles CH, Eccersley AJ, Scott SM, Walker S, Reeves B, Lunniss PJ. Linear discriminant analysis of symptoms in patients with chronic constipation: validation of a new scoring system (KESS). Dis Colon Rectum. 2000;43:1419-26.

20. Law PA, Danin JC, Lamb GM, Regan L, Darzi A, Gedroyc WM. Dynamic imaging of the pelvic floor using an open-configuration magnetic resonance scanner. J Magn Reson Imaging. 2001;13:923-9.

21. Lehur PA, Stuto A, Fantoli M, Villani RD, Queralto M, Lazorthes F, Hershman M, Carriero A, Pigot F, Meurette G, Narisetty P, Villet R; ODS II Study Group. Outcomes of stapled transanal rectal resection vs. biofeedback for the treatment of outlet obstruction associated with rectal intussusception and rectocele: a multicenter, randomized, controlled trial. Dis Colon Rectum. 2008;51:1611-18.

22. Lienemann A, Anthuber C, Baron A, Kohz P, Reiser M. Dynamic MR colpocystorectography assessing pelvic floor descent. Eur Radiol. 1997;7:1309-17.

23. Maeda Y, Lundby L, Buntzen S, Laurberg S. Sacral nerve estimulation for constipation: suboptimal outcome and adverse events. Dis Colon Rectum. 2010;53:995-9.

24. Mahieu P, Pringot J, Bodart P. Defecography: I. Description of a new procedure and results in normal patients. Gastrointest Radiol. 1984;9:247-51.

25. Marti MC, Roche B, Deléaval J. Rectoceles: value of video-defecography in selection of treatment policy. Colorectal Dis. 1999;1:324-9.

26. Mellgren A, Anzén B, Nilsson BY, Johansson C, Dolk A, Gillgren P, Bremmer S, Holmström B. Results of rectocele repair: a prospective study. Dis Colon Rectum. 1995;38:7-13.

27. Mimura T, Roy AJ, Storrie JB, Kamm MA. Treatment of impaired defecation associated with rectocele by behavorial retraining (biofeedback). Dis Colon Rectum. 2000;43:1267-72.

28. Murad-Regadas SM, Regadas FS, Rodrigues LV, Silva FR, Soares FA, Escalante RD. A novel three-dimensional dynamic anorectal ultrasonography technique (echodefecography) to assess obstructed defecation, a comparison with defecography. Surg Endosc. 2008;22:974-9.

29. Murad-Regadas SM, Regadas FS, Rodrigues LV, Oliveira L, Barreto RG, de Souza MH, Silva, FR. Types of pelvic floor dysfunctions in nulliparous, vaginal delivery, and cesarean section female patients with obstructed defecation syndrome identified by echodefecography. Int J Colorectal Dis. 2009;10:1227-32.

30. Pemberton JH, Rath DM, Ilstrup DM. Evaluation and surgical treatment of severe constipation. Ann Surg. 1991;214:403-13.

31. Porter WE, Steele A, Walsh P, Kohli N, Karram MM. The anatomic and functional outcomes of defect-specific rectocele repairs. Am J Obstet Gynecol. 1999; 181:1353-59.

32. Regadas FS, Haas EM, Abbas MA, Marcio Jorge J, Habr-Gama A, Sands D, Wexner SD, Melo-Amaral I, Sardiñas C, Lima DM, Sagae EU, Murad-Regadas SM. Prospective multicenter trial comparing echodefecography with defecography in the assessment of anorectal dysfunctions in patients with obstructed defecation. Dis Colon Rectum. 2011;54:686-92.

33. Roman H, Michot F. Long-term outcomes of transanal rectocele repair. Dis Colon Rectum. 2005;48:510-7.

34. Shorvon PJ, McHugh S, Diamant NE, Somers S, Stevenson. Defecography in normal volunteers: results and implications. Gut. 1989;30:1737-49.

35. van Dam JH, Schouten WR, Ginai AZ, Huisman WM, Hop WC. The impact of anismus on the clinical outcome of rectocele repair. Int J Colorectal Dis. 1996 $11: 238-42$

36. Watson SJ, Loder PB, Halligan S, Bartram CI, Kamm MA, Phillips RK. Transperineal repair of symptomatic rectocele with Marlex mesh: a clinical, physiological and radiologic assessment of treatment. J Am Coll Surg. 1996;83:257-61.

Received 22/10/2011 Accepted 18/12/2011 